\title{
Article
}

\section{Transatlantic communication in the early years of the International Scientific Series (1871 to 1875)}

\author{
Howard J. Swatland
}

\begin{abstract}
The first 18 volumes of the International Scientific Series published in both London and New York were reviewed to assess their contribution to transatlantic communication of popular science. The dominant flow of ideas was westwards on topics such as science versus religion, empiricism in psychology, survival of the fittest, jurisprudence versus mental illness, economics and development of cinematography. There was an eastward flow in philology. The preparation of volumes was rushed and many authors merely expanded previous notes, articles and pamphlets. Commercial and idealistic motives conflicted. There were disagreements among authors. Despite all this, the series had a lasting effect on social thought.
\end{abstract}

\section{Introduction}

The balance between popular entertainment and scholarly education is crucial in science communication. ${ }^{1}$ At a time when the trivialization of entertainment was perceived as a threat to education, Edward Livingston Youmans (1821-1887), the leading American science popularizer of his day, attempted to move the balance towards serious scholarship by founding the International Scientific Series (ISS). ${ }^{2}$ This was a revolution in science communication and commercial practice - international authors publishing simultaneously in English, French, German, Italian and Russian, and being paid royalties voluntarily before international authors' rights were established. But perfect coordination did not last very long, and the series began to diverge in each country. Henry S. King published the first British volumes and their historical importance was analyzed by MacLeod in 1980..$^{3}$ D. Appleton and Company, with whom Youmans had a close relationship, published all the American volumes. The book history of the ISS was described by Howsam in $2000 .^{4}$

Here we will examine the trend-setting early British and American volumes in the ISS (figure 1), using Roman numerals for British, and Arabic numerals for American volumes. How were they involved in transatlantic science communication, and did the ISS achieve its stated objective of purifying popular science publishing? These are complex questions. The space allowed for this paper limits us to a summary of the main points. 


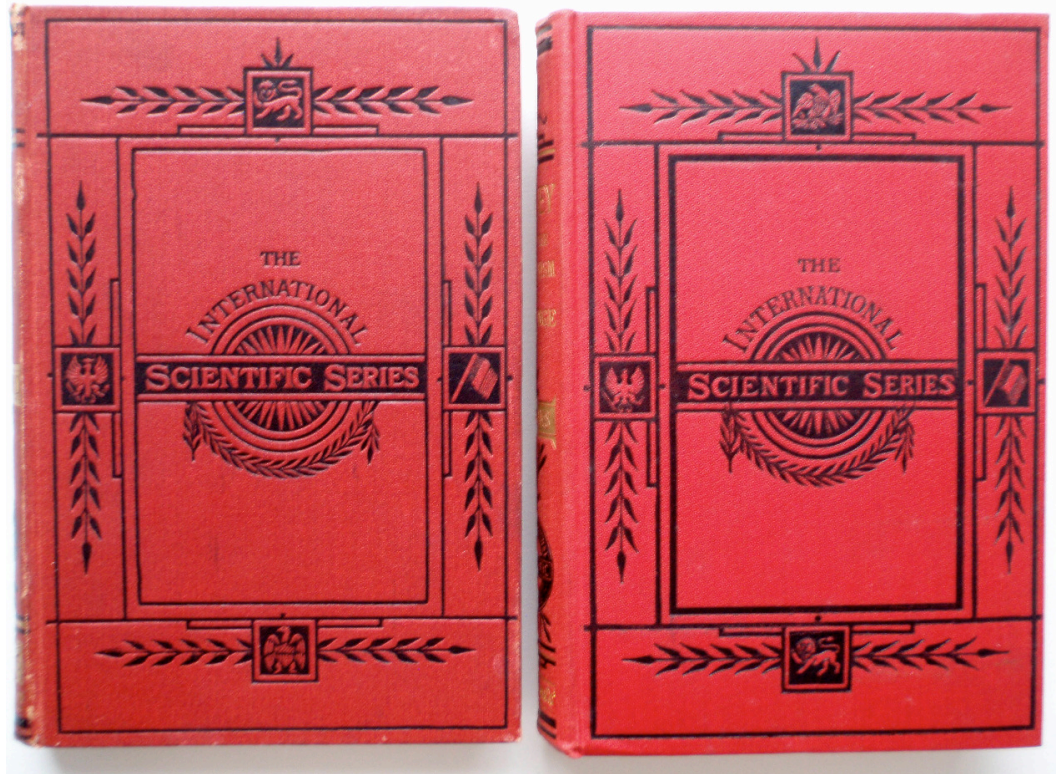

Figure 1. British (left) and American (right) volumes of the ISS with appropriate dominance of the national symbols.

I (1) John Tyndall. The Forms of Water in Clouds and Rivers, Ice and Glaciers.

John Tyndall (1820-1893) was born in Ireland and worked as a draftsman, engineer and surveyor before earning a doctorate from the University of Marburg and becoming Professor of Natural Philosophy at the Royal Institution in London. He made important discoveries on light scattering and was well known as a popularizer of science. In 1869, he helped inaugurate Nature, which is still one of the leading scientific journals. Tyndall wrote the first ISS volume (London, 1871). It was highly popular as well as scientifically progressive, but the ensuing transatlantic communications were too late for the American expert in this field, Jean Agassiz at Harvard who died in 1873. Agassiz's work was explained in Tyndall's volume.

To exploit Tyndall's popularity, the American edition carried a portrait of him as frontispiece instead of a cloud above the French Alps. Youmans launched the ISS with a strongly worded 1872 preface for the American edition, "The tendency of careless and unscrupulous book-makers to cater to public ignorance and love of the marvelous, and to foist their crude productions upon those who are too little instructed to judge their real quality, has hitherto been so strong as to cast discredit upon the idea of popular science". This was judged an "evil tendency" for which the ISS would be the remedy "strong in character, moderate in price". The American edition corrected typographical errors (crevasse for creva $\sim$ se on p. 57) but introduced others (claiming 35 instead of 25 illustrations). Apart from the title page, stereotypes of the woodcuts and letterpress were shipped across the Atlantic with few changes. The transatlantic flow of ideas was bi-directional and, in the author's forward, Tyndall agreed with Ralph Waldo Emerson that education should be half instruction and half provocation. Another prescient note may strike a modern reader, for Tyndall starts his work with, "After an absence of twelve years, I visited the Mer de Glace last June. It exhibited in a striking degree that excess of consumption over supply which, if continued, will eventually reduce the Swiss glaciers to the mere spectres of their former selves".

II (2) Walter Bagehot. Physics and Politics.

Walter Bagehot (1826-1877) had a respected position in British commerce and journalism as editor of the The Economist, also still with us as a leading journal. Bagehot's 1867 book The English Constitution is still valued as a comparison of British and American forms of government, and he brought American affairs into the purview of the The Economist. ${ }^{6}$ The subtitle of his ISS volume is Thoughts on the application of the principles of "natural selection" and "inheritance" to political science. The work was an extension of material previously published in the Fortnightly Review and was published in London in 1872 and in New York in 1873. Thoughts is an accurate description of the volume, since there is little 
trace of politics and none of physics. It is highly parochial. Were American readers familiar with the life and characters across the Atlantic or did these points escape them? Bagehot stated that politics and political economy are old sciences, which infers a broad definition of science and explains the later inclusion of many fringe topics in the ISS. Whereas Tyndall supported his conclusions with original data, Bagehot did so by appealing to the preconceived prejudices of his readers. At best, this is a mirror to what readers were thinking, for example, that the people of a savage tribe resembled a herd of gregarious beasts.

\section{III (3) Edward Smith. Foods.}

Edward Smith (1819-1874) was a British physician with personal transatlantic connections via his American wife. ${ }^{7}$ In his day he may not have been properly appreciated, but his contribution to the ISS is remarkable. Essentially, it is the first textbook of food science in the English language and is firmly based on biochemical and physiological grounds, but with valuable historical and sociological commentaries. Smith was the first to consider the gaseous content and exposure of foods, thus establishing the scientific foundation of our modern food packaging industries. The first of ten extensively illustrated (155 figures) editions was published in London in 1873, but not until 1876 in New York. His later work on meat extracts engendered lively European communications with Justus von Liebig ${ }^{7}$ which were probably read by American agricultural chemists gathering in the Morrill Land-Grant Colleges (1862-1890).

IV (4) Alexander Bain. Mind and Body. The Theories of their Relation.

Alexander Bain (1818-1903) started life as a weaver and rose to become one of the founders of the British school of empiricism - psychology as a manifestation of sensory physiology. Bain founded Mind, another journal still paramount in its field. The short delay between British and American publications (1873 versus 1874) may have facilitated transatlantic communication relating to British empiricism versus American pragmatism, with an outcome extending far beyond the ISS.

V (5) Herbert Spencer. The Study of Sociology.

Herbert Spencer (1820-1903) wrote this volume for the ISS at the urging of Youmans in 1871 and it became the third best seller by $1894 .{ }^{2}$ The British volume published in 1873 ran to 22 editions and the American volume was published in 1875. Hundreds of thousands of copies were sold, and the ISS royalty agreement was doubtless important for the now independently wealthy philosopher. Spencer simplified the complexities of natural selection to "survival of the fittest" and applied this ruthlessly to everything sociological or historical, with enormous and persistent effects on both sides of the Atlantic.

VI (7) Balfour Stewart. The Conservation of Energy.

Balfour Stewart (1828-1887) made important discoveries on radiant heat and discovered factors affecting terrestrial magnetism. His volume on electromechanical equivalence was published in London in 1873 and in New York in 1874. Youmans wrote a preface to the American edition in 1873 explaining why he had added two essays to the otherwise slim British volume. The first essay extended coverage to biochemical topics and was by Joseph Le Conte, Professor of Geology and Natural History at the University of California, who thus became the first American contributor to the ISS. The second essay on the correlation of nervous and mental forces was by Alexander Bain who thus became the first to make a repeat contribution to the ISS.

VII (8) J. Bell Pettigrew. Animal Locomotion or Walking, Swimming, and Flying, with a Dissertation on Aëronautics.

James Bell Pettigrew (1834-1908) was a Scottish anatomist still remembered for his work on the arrangement of muscle fibres directing a complex pattern of blood flow in the heart. ${ }^{8}$ The volume was published in London in 1873 and in New York in 1874. It was soon followed by a similar volume from Marey (XI, 11) and the two authors disagreed. ${ }^{9}$ Pettigrew's slant towards the future development of aviation was more towards the ornithopter than the glider, which ultimately proved feasible, but air flow on a wing surface is prominent in his writing. Did Wilbur Wright ever read the widely available Appleton volume published when he was very young? He wrote to the Smithsonian for help in a literature search, saying he was familiar with Marey's and Jamieson's books published by Appleton's. ${ }^{10}$ There is no trace of a Jamieson book (on applied mechanics) published by Appleton, and subsequent correspondence (Jan 23 and Jan 29) reveals he meant Pettigrew when he wrote Jamieson. ${ }^{11}$ 
VIII (9) Henry Maudsley. Responsibility in Mental Disease.

Henry Maudsley (1835-1918) was the best known British psychiatrist of the Victorian era. ${ }^{12}$ His volume deals with jurisprudence, mostly British but also including the Court of New Hampshire. Published in 1874 in both London and New York, this volume had some influence on American jurisprudence, ${ }^{13}$ but it is difficult to separate from the effects of Maudsley's other books. ${ }^{14}$

IX (6) Josiah Parsons Cooke. The New Chemistry.

Josiah Parsons Cooke (1827-1894) was Erving Professor of Chemistry and Mineralogy at Harvard University. His work on atomic weights dominates the volume published first in New York in 1873 and then in London in 1874 (11 editions). This was the first full American volume in the ISS. Cooke made an early attempt at the classification of the elements, and his volume became the second best seller in the ISS. $^{2} \mathrm{He}$ was one of the few ISS authors who were able to update their work with a thorough revision for a second edition (1891). However, as an unsuccessful precursor to the periodic table, there is little evidence of this ISS volume contributing much to transatlantic science communication.

X (10) Sheldon Amos. The Science of Law.

Sheldon Amos (1835-1886) was Professor of Jurisprudence at University College, London. His volume was published in London in 1874 and in New York in 1875. At a time when American jurisprudence was actively developing while Britain was lagging behind, little if any transatlantic communication may have arisen from this volume. By modern standards, the book is devoid of scientific content.

XI (11) E.J. Marey. Animal Mechanism. A Treatise on Terrestrial and Aerial Locomotion.

Étienne-Jules Marey (1830-1904) was the first Continental European contributor to the ISS (both London and New York in 1874). As Professor at the Collège de France and a leading French physiologist he is remembered for his innovative approach to physiological recording using a variety of transducers to operate pens on smoked drums. These are nicely illustrated in his volume. Pettigrew had dismissed Marey's work, and so Marey dismissed Pettigrew's work. Both authors were read by Wilbur Wright, but with minimal effect because aeroplane design advanced rapidly in the $1870 \mathrm{~s} .{ }^{15}$ Far more important was the fact that Marey had invented a portable camera which looked like a shotgun and enabled him to obtain a series of photographs of birds in flight. This is widely recognized as an important step in the development of cinematography - he was the first to pan a camera on a moving subject. ${ }^{16}$ Then followed citations and technology transfers too numerous to mention, culminating in the American motion picture industry.

XII (13) Oscar Schmidt. The Doctrine and Descent of Darwinism.

Eduard Oscar (Oskar) Schmidt (1823-1886) was a German invertebrate zoologist and Professor at the University of Strasburg. ${ }^{17}$ The first of his eight editions was published in both London and New York in 1875. Schmidt's provocative ideas are still extensively cited, mainly for his introduction of the term 'social Darwinism', ${ }^{18}$ with extensive spin-offs in religious and racist literature. Schmidt's volume was an expansion of an earlier pamphlet. Schmidt included Othniel Marsh's palaeontological works, showing American discoveries were followed from across the Atlantic. Not only did Schmidt agree with the descent of birds from dinosaurs but, with great discernment, he juxtaposed whales with ungulates something now proven by molecular phylogeny and cladistics. ${ }^{19}$

XIII (12) John William Draper. History of the Conflict Between Religion and Science.

John William Draper (1811-1882) was born in Britain and educated at London University where he became interested in photochemistry. After emigrating to America in 1832 he continued with medical and chemical studies, and became Professor at the University of New York. He discovered that light must be absorbed to produce a chemical effect and that all solids glow red at about the same temperature. He had a string of firsts in photography including the moon through a telescope, tissues through a microscope and a diffraction spectrum. Having switched from science to history, in 1873 he was writing the best seller in the ISS, to be published in New York in 1874 and in London in 1875. Eight editions were published in London within a year, eventually running to 24 . The widely used term 'conflict thesis', denoting science versus religion, derives from the title of this ISS volume. The transatlantic citations are 
too numerous to enumerate. Clearly this volume was to be a target for critical attack, even nowadays from those siding with science against religion.

XIV (15) M.C. Cooke. Fungi: Their Nature, Influence and Uses.

Mordecai Cubitt Cooke (1825-1914) was a British botanist who had started working as an apprentice and clerk, and finished with honours from the Linnean Society. Initially the volume was solicited from Miles Joseph Berkeley (1803-1889), a British clergyman and outstanding botanist who had identified the fungal cause of the Irish potato famine which had killed a million and caused countless others to emigrate to America. Berkeley passed the invitation to Cooke and then became his editor. Cooke had received honorary degrees from American universities and Berkeley had excellent credentials in transatlantic communication, having helped with identification of specimens collected during Commodore Perry's gunboat diplomacy in the North Pacific aimed at opening trade with Japan. ${ }^{20}$ Strangely, for a volume destined for co-publication in Britain and America in 1875, no details were given of American fungi, even though Berkeley had first-hand experience. ${ }^{21}$

XV (14) Hermann Vogel. The Chemistry of Light and Photography in their Application to Art, Science, and Industry.

Hermann Willhelm Vogel (1834-1898) was Professor in the Royal Industrial Academy of Berlin where he worked to improve the spectral sensitivity of photographic emulsions. His volume with high-quality, tipped-in photographic plates was published in 1875 in both London and New York, and immediately created problems which led to a series of amendments and later revisions. Publishing in an area where Draper (XII, 12) was an acknowledged master, Vogel completely ignored all Draper's work and used a photograph of the moon from Lewis Rutherford as frontispiece. The embarrassment was sufficient for Youmans to add an 1875 appendix to the American edition explaining Draper's priorities, particularly that Draper's moon photograph had been exhibited in New York in 1840. Was this a lack of transatlantic communication or Vogel's professional jealousy?

XVI (16) William Dwight Whitney. The Life and Growth of Language: an Outline of Linguistic Science.

William Dwight Whitney (1827-1894) was Professor of Sanskrit and Comparative Philology at Yale College. He rewrote a previous transatlantic book telling "the old story in a new way". Published in 1875 in both New York and London, this volume had a major transatlantic impact ${ }^{22}$ difficult to separate from that of the first book.

XVII (17) W. Stanley Jevons. Money and the Mechanism of Exchange.

William Stanley Jevons (1835-1882) was an economist and logician and held Professorships first at Owens College, Manchester, then at University College, London. His volume was published in 1875 in both London and New York. His contribution to what would later become known as marginal utility theory was incorporated into American economic theory. ${ }^{23}$

XVIII (18) Eugene Lommel. The Nature of Light, with a general Account of Physical Optics.

Eugen Cornelius Joseph von Lommel (1837-1899) was a mathematician as well as Professor of Physics at the University of Erlangen in Germany. His volume (London, 1875, and New York, 1876) has a chromolithograph of spectra and a mixture of borrowed and original woodcuts. The chromolithograph was soon borrowed for an American text on colorimetry. ${ }^{24}$

\section{Discussion}

The ISS has been studied from two approaches, history of science by MacLeod ${ }^{3}$ and history of books by Howsam, ${ }^{4}$ with some overlapping. MacLeod used publisher's records of the numbers of editions of British volumes ${ }^{25}$ and Howsam took scientific content into account. Both approaches overlap with this assessment of the ISS as a medium for transatlantic scientific communication. It is appropriate, therefore, to separate the intentions of the three approaches. In the first approach, the historian of science tends to assume that current scientific knowledge is correct and seeks to find its source, often dismissing communication of incorrect ideas as dead ends. ${ }^{26}$ In the second approach, the historian of books is 
concerned mostly with the archeology of the hard copy, but the printed page has never been the sole means of communication and there are numerous gaps in what has survived. In the third approach, the study of science communication, all aspects of how scientific information is transmitted are of interest both correct and incorrect information, both artifact and process, both motive and effect. Ninety-eight volumes were published in the ISS by 1925. Almost any argument is supportable by the biased selection of examples, which is why it is important to consider them one by one.

How was the ISS involved in transatlantic scientific communication? For the period 1871 to 1875 , it was mainly a westward flow of new ideas and an eastward flow of appreciation. Some volumes changed the way Americans viewed the stock market and the biblical Book of Genesis. But, as would be expected for popular science, the ISS had only a little effect on active scientists who were communicating by reading professional journals, writing personal letters and visiting each other. For the newer academic disciplines such as psychology, philology, nutrition and sociology with few professional journals, there may have been a stronger effect than for older disciplines with numerous journals.

Did the ISS raise the standard of popular science communication? The answer is a guarded yes - for those with an original content. Did the ISS purify the "evil content" of commercial exploitation of popular science publishing? The answer is not really. In 1871, Jules Verne and H.G. Wells were starting to steal the most lucrative part of the market with startling works of science fiction. King and Appleton were commercial publishers and were probably happy to secure the intellectual high-ground if it made a profit in a high-volume, low-price market. Does this help explain why they included law books in the ISS? Even the idea of an ornamental series of books is a little cynical, anticipating how many books might be purchased as decorations for a book shelf. ${ }^{27}$ But spines aesthetically collated by bibliophiles soon would be dispersed and defaced with call numbers by librarians following Melvil Dewey's more utilitarian rules of serialization (1876). For the content of the ISS, the real problem came from within the process of publishing.

Imagine what it was like to be a scientist in 1871. Many had risen from humble origins and had fought their way to one of a few paid positions. Almost certainly they had domestic servants at home, but laboratory technicians were still rare. A pen was used for writing, often by gaslight. Then comes a letter or a visit from Youmans requesting rapid production of a volume for the ISS. The requests often went to those already busy with other books or journals they had founded. Even scientists with the highest scientific integrity relaxed their standards for a work of popular science by expanding earlier notes or pamphlets to a book. Much of Tyndall's founding volume reads like Jules Verne's Journey to the Centre of the Earth (1864) - written in the first person as an adventure narrative and sprinkled with namedropping scientific observations. Tyndall, always honest, tells us in his preface that the book was derived, at the urgent request from a friend, from notes distributed to a youthful audience at the Royal Institution. And there is evidence of recycling in most of the ISS volumes. Thus, 18 volumes of the ISS were produced very rapidly. It looks as if the rush to obtain market precedence for a series with matching, eyecatching bindings was more important than crafting a series of books with a coherent style of communication. But how many well-known scientists would have had time to write a book de novo for the general public? Without great names there might be no great sales - a disappointment for both publishers and idealistic communicators of popular science. There are few doubts about the idealism. Tyndall, for example, embarrassed at having made the huge sum of $\$ 23,100$ for his invited lecture visit to America in 1871 during the planning phase of the ISS, promptly endowed an American scholarship fund with the surplus above expenses. ${ }^{28}$

In this cursory examination of the highlights of an important era in science communication we may find, therefore, abundant evidence of familiar problems: (1) pressure to publish, (2) conflicting commercial and idealistic motives, and (3) personal confrontations. Science may advance, but does human nature?

\section{Notes and references}

1 A. Singhal and E.M. Rogers (1999), Entertainment - Education. A Communication Strategy for Social Change, Lawrence Erlbaum Associates, New Jersey.

2 J. Fiske (1894), Edward Livingston Youmans, D. Appleton and Company, New York. Un-referenced biographic details originate from the Concise Dictionary of Scientific Biography, Charles Scribner's Sons, New York (1981).

3 R.M. MacLeod (1980), Evolutionism, internationalism and commercial enterprise in science: the International Scientific Series 1871-1910, in A.J. Meadows (ed.), Development of Science Publishing in Europe, Elsevier, Amsterdam. 
${ }^{4}$ L. Howsam (2000), An experiment with science for the nineteenth-century book trade: the International Scientific Series, British Journal of the History of Science 33: 187-207.

5 J.S. Rowlinson (1981), Tyndall's work on glaciology and geology, in W.H. Brock, N.D. McMillan and R.C. Mollan (eds.) John Tyndall. Essays on a Natural Philosopher, Royal Dublin Society, Historical Studies in Irish Science and Technology.

6 N. St John-Stevas (1959), Walter Bagehot. A Study of his Life and Thought together with a Selection from his Political Writings, Eyre \& Spottiswoode, London

7 K.J. Carpenter (1991), Edward Smith (1819-1874), Journal of Nutrition 121: 1515-1521.

8 J. Narula, M.A. Vannan and A.N. DeMaria (2007), Of that waltz in my heart, Journal of the American College of Cardiology 49: 917-920.

9 P. Souriau (1983), Aesthetics of Movement, University of Massachusetts Press, Amherst.

${ }^{10}$ W. Wright (1899), Letter to the Smithsonian, May 30

${ }_{11}^{11}$ M.W. McFarland (1953), The Papers of Wilbur \& Orville Wright, Including the Chanute-Wright Papers, McGraw-Hill, New York.

${ }^{12}$ E. Shorter (1997), A History of Psychiatry: From the Era of the Asylum to the Age of Prozac, John Wiley, New York.

${ }^{13}$ J.W. Springthorpe and W.L. Mullen (1893), Medical jurisprudence on the plea of insanity in criminal trials, American Journal of Insanity 49: 402-428.

${ }^{14}$ J. Colaizzi (1989), Homicidal Insanity, 1800-1985, University of Alabama Press, Tuscaloosa.

${ }^{15}$ C.H. Gibbs-Smith (1967), A Brief History of Flying. Science Museum, London.

${ }^{16}$ R.M. Barsam (1973), Non-fiction Film: a Critical History, Bloomington, Indiana University Press.

17 “Sketch of Oscar Schmidt" Appletons' Popular Science Monthly, New York, September, p. 693-700 (1899).

${ }^{18}$ O. Schmidt (1879), Science and Socialism, Popular Science Monthly 14: 577-591.

${ }^{19}$ D. R. Prothero and S.E. Foss (2007), The Evolution of Artiodactyls, Johns Hopkins University Press, Baltimore.

${ }^{20}$ M.J. Berkeley and M.A. Curtis (1857-1860), Characters of new fungi, collected in the North Pacific Exploring Expedition by Charles Wright, Proceedings of the American Academy 4: 111-130.

${ }^{21}$ M.J. Berkeley and M.A. Curtis (1853), Centuries of North American fungi, Annals and Magazine of Natural History Ser. II, 12: 417-435, and (1859) Ser. IV 3: 284-296.

${ }^{22}$ V. Law (2003), The History of Linguistics in Europe from Plato to 1500. University Press, Cambridge.

${ }^{23}$ M. Perlman and C.R. McCann (1998), The Pillars of Economic Understanding: Ideas and Traditions, University of Michigan Press, Ann Arbor.

${ }^{24}$ E.D. Babbit (1878), Light and Color. Babbit \& Co, New York.

${ }^{25}$ Some numbers of editions reported here were taken from MacLeod and are minimum values, because his data concluded in 1909. Thus, volume LXX (76) first published in 1896 only has one edition by 1909, whereas there were nine editions by 1925 .

${ }^{26}$ This was the fate of Cooke's work (V, 6) in A.J. Ihde (1964), The Development of Modern Chemistry, Harper \& Row, New York.

${ }^{27}$ This study is based on inexpensive ISS books collected from 1959 to 2009. I regret I did not record when I cut pages to expose the text for the first time, which might have provided insights into what had been read or examined by previous owners.

${ }^{28}$ I.B. Cohen (1959), Some reflections on the state of science in America during the Nineteenth Century, Proceedings of the National Academy of Sciences 45: 666-677.

\section{Author}

The author is a Professor Emeritus at the University of Guelph where he worked in histochemistry and the development of fibre-optic sensors. He now indulges in a wide range of scientific interests with recent refereed publications in science communication, food consumption culture, and polarized-light interferometry of crystal structures. His current research is on groundwater hydrology and ecological photometry.E-mail: swatland@uoguelph.ca.

How TO CITE: H.J. Swatland, Transatlantic communication in the early years of the International Scientific Series (1871 to 1875), Jcom 09(02) (2010) A03. 